\title{
MULTI STAGE WHEAT YIELD ESTIMATION USING DIFFERENT MODEL UNDER SEMI ARID REGION OF INDIA
}

\author{
Ananta Vashisth, P. Krishanan and D. K. Joshi \\ Division of Agricultural Physics \\ ICAR-Indian Agricultural Research Institute, New Delhi \\ E-mail: ananta.iari@gmail.com
}

Commission III, WG III/10

KEY WORDS: Wheat, Crop Yield Estimation, Crop Simulation Model, Weather Based Model, Flowering Stage, Grain Filling Stage

\begin{abstract}
Crop yield estimation before harvest is required for marketing, pricing, storage, import, export etc. Productivity of cropping systems under various weather, management and policy scenarios can be predicted successfully by simulation models. Due to increase in input cost of agricultural operation, agriculture produces become costly. Therefore, crop yield estimation in the agriculture becomes essential. Weather variability causes the losses in the yield. Therefore, model based on weather parameters, soil parameter and crop parameters can provide reliable crop yield estimation in advance. For estimating the multi stage wheat crop yield, experiments were conducted at research farm of IARI, New Delhi during Rabi 2016-17 and Rabi 2017-18. Crop yield were estimated by weather based and crop simulation model. Percentage deviation of estimated yield by observed yield at flowering and grain filling stage was -5.1 and 2.0 by weather based model, 4.3 and 2.1 by InfoCrop model, 10.2 and 9.0 by DSSAT model during Rabi $2016-17$ and 5.3 and 5.9 by weather based model, 2.3 and 2.2 by InfoCrop model, -10.8 and -9.6 by DSSAT model during Rabi 2017-18 respectively. Among the three models opted for estimating the yield at flowering and grain filling stage, InfoCrop model gave better results followed by weather based and DSSAT model. Therefore, this model can be used for multi stage wheat crop yield estimation at district as well as regional level
\end{abstract}

\section{INTRODUCTION}

Wheat (Triticum aestivum L.) is an important cereal crop in India occupying second place, next to rice in production, which plays a critical role in food security. Among all commercially grown crops, it occupies largest land area, i.e. more than 240 million ha and it ranks highest in terms of production. Wheat is grown in almost all the states of India. It is grown in Rabi season in the northern India. Estimation of crop production at different stages of crop growth before harvest is useful for farmers and planners for preparing advance planning, formulation and its implementation in regard to crop procurement, distribution, price structure and import/export decisions. Productivity of cropping systems under various weather, management and policy scenarios can be predicted successfully by simulation models. The main factors affecting crop yield are weather, soil and genetic coefficient of the crop. Weather plays an important role in crop growth. Therefore, crop simulation model based on weather parameters, soil parameter and crop parameters can provide reliable forecast in advance for crop yield.

Crop yield estimation is typically issued at different stages between the time of planting and time of harvest. The success of the crop yield estimation strongly depends on the crop simulation model's ability to quantify the influence of weather, soil and management conditions on crop yield and on the system's ability to properly integrate model simulation results over a range of spatial scales. The spatial and temporal Variability of weather conditions are an important source of uncertainty when applying models over large areas. Efforts in the past has been made by several researchers to develop statistical models based on time series data on crop yield and weather variables for pre harvest crop yield forecast. Agrawal et al. (2012) have developed forecast models for wheat yield in Kanpur district using discriminant function analysis of weakly data on weather variables. Ghosh et al (2014) reported that the performance of the district level yield forecast model developed using composite weather indices in predicting yields at district level for various major crops in different states of the country is quite satisfactory. Vashisth, et al (2015) reported that percentage deviation of the average observed yield by average estimated yield done at twenty days before harvest by InfoCrop in maize crop was 5.5 and $2.9 \%$ in maize and mustard respectively. Vashisth, et al (2014) reported that the statistical models based upon the weather indices could successfully simulate pre harvest yield forecast of wheat under semi-arid region. The percentage deviation between observed and simulated yield was ranged from 5 to 11 and the correlation coefficient was 0.93 to 0.99 . Therefore it can be used for district, agro climatic zone and state level forecast. InfoCrop has been successfully adapted, calibrated and validated for rice, (Aggarawal et al., 2006), potato (Singh et al., 2005), cotton (Hebbar et al., 2008) etc. The prime aim of this study is to develop, calibrate and validate crop yield estimation for wheat at flowering and grain filling stage based on the field experiment at IARI research farm using Weather based, InfoCrop and DSSAT model.

\section{MATERIALS AND METHODS}

Field experiments were conducted at IARI, New Delhi research farm during Rabi 2016-17 and Rabi 2017-18 seasons respectively for estimating multi stage crop yield for wheat 
using, weather based, InfoCrop and DSSAT model. The climate of the station is semiarid with dry hot summers and cold winter. Three varieties of wheat viz., HD-2967, HD-3086 and PPW723 , were sown on three different dates to generate the weather variability at different phenological stages during Rabi 2016-17 and Rabi 2017-18. The crop was raised following the standard agronomic practices with three replications in a randomized block design. Number of days required to attain different phenological stages were recorded. Genetic coefficients (specific leaf area, relative growth rate of leaf area, index of greenness of leaves, root growth rate, radiation use efficiency etc.) were measured for running crop simulation models for multi stage crop yield estimation. InfoCrop model is used for simulation of yield. The input requirement for InfoCrop models are sowing depth, seed rate $(\mathrm{kg} / \mathrm{ha})$, sowing date, germination date, flowering date, maturity date, harvesting date, days/interval of irrigation, amount of irrigation, days/interval and amount of fertilizer, maximum and minimum temperature, wind speed, rainfall, solar radiation, morning and evening relative humidity. Daily weather data were collected from the agromet observatory located in the research farm of IARI, New Delhi. The soil data required for crop models are soil texture, structure, depth, profile, level of soil nutrients, and other related variables that describe the soil-water balance and nutrient dynamics during crop growth and development. Soil physical characteristics such as hydraulic conductivity determine the movement of water in the soil. Besides, field capacity, wilting point, bulk density are also required. Soil samples were collected from experimental location of IARI, New Delhi for characterization and testing of models. The soil was sandy loam. Estimation of crop yield was done at flowering and grain filling stage using weather based statistical model, InfoCrop model and DSSAT model. Percentage deviation of estimated yield was done by the observed yield using the following formula:

$\%$ Deviation $=[($ Estimated Yield - Observed Yield)*100]/Observed yield

The crop yield forecast models used stepwise regression analysis. Weather variables are used as independent variables which are related to crop responses such as yield and to account for the technological changes, function of time is used as independent variables.

$$
\begin{gathered}
Y=A_{0}+\sum_{i=1}^{p} \sum_{j=0}^{1} a_{i j} Z_{i j}+\sum_{i \neq i^{\prime}=1}^{p} \sum_{j=0}^{1} a_{i i^{\prime} j} Z_{i i^{\prime} j}+c T+e \\
Z_{i j}=\sum_{w=1}^{m} r_{i w}^{j} X_{i w} \quad \text { and } Z_{i i^{\prime} j}=\sum_{w=1}^{m} r_{i i^{\prime} w}^{j} X_{i w} X_{i^{\prime} w}
\end{gathered}
$$

Where

$r_{i w}$ is correlation coefficient of yield with $i$-th weather variable in w-th period

$\mathrm{r}_{\text {ii' }}$ is correlation coefficient (adjusted for trend effect) of yield with product of $i$-th and $i$ '-th weather variables in $w$-th period $\mathrm{m}$ is period of forecast

$p$ is number of weather variables used

e is random error distributed as $\mathrm{N}\left(0, \sigma^{2}\right)$

Weather indices used for developing weather-based model is given in table as below

\begin{tabular}{|l|l|l|l|l|l|}
\hline \multicolumn{6}{|l|}{ Simple weather indices } \\
\hline & Tmax & Tmin & Rain & RH I & RH II \\
\hline Tmax & Z10 & & & & \\
\hline Tmin & Z120 & Z20 & & & \\
\hline Rain & Z130 & Z230 & Z30 & & \\
\hline RH I & Z140 & Z240 & Z340 & Z40 & \\
\hline RH II & Z150 & Z250 & Z350 & Z450 & Z50 \\
\hline Weighted weather indices & Tmax & Tmin & Rain & RH I & RH II \\
\hline \multicolumn{7}{|l|l|l|l|}{} \\
\hline Tmax & Z11 & & & & \\
\hline Tmin & Z121 & Z21 & & & \\
\hline Rain & Z131 & Z231 & Z31 & & \\
\hline RH I & Z141 & Z241 & Z341 & Z41 & \\
\hline RH II & Z151 & Z251 & Z351 & Z451 & Z51 \\
\hline
\end{tabular}

Model performance was evaluated by calculating the different statistical parameters viz. root mean square error (RMSE), correlation coefficient and standard deviation. RMSE describe the mean absolute deviation between observed and simulated and accuracy of model is characterized by lower RMSE.

\section{RESULTS AND DISCUSSION}

\section{Weather during Rabi 2016-17 at IARI, New Delhi}

The maximum temperature during different standard meteorological weeks in the Rabi 2016-17 was observed to be lower than normal except during $47^{\text {th }}, 48^{\text {th }}, 1^{\text {st }}, 3^{\text {rd }}$ to $10^{\text {th }}$ and $12^{\text {th }}$ to $16^{\text {th }}$ standard meteorological week it was found to be higher than normal. The difference between normal and observed maximum temperature was -2.3 to 5.4 in different standard meteorological weeks. The minimum temperature remain lower than normal except during $1^{\text {st }}, 3^{\text {rd }}$ to $10^{\text {th }}$ and $12^{\text {th }}$ to $16^{\text {th }}$ standard meteorological weeks it was higher than normal. The minimum temperature was 0.2 to $5.3^{\circ} \mathrm{C}$ higher than normal and -5.2 to $-2.0^{\circ} \mathrm{C}$ lower than normal in different standard meteorological weeks. The difference between observed and normal maximum temperature was -5.2 to $5.3^{\circ} \mathrm{C}$ during different standard meteorological weeks. Total rainfall of 89.9 $\mathrm{mm}$ (normal value $102.9 \mathrm{~mm}$ ) was received during Rabi 201617 on $1^{\text {st }}, 4^{\text {th }}, 10^{\text {th }}, 11^{\text {th }}$ and $14^{\text {th }}$ standard meteorological weeks. The rainfall during the Rabi season was less than the normal. However, the rainfall was received in 5 out of 22 weeks of this season. Bright sunshine hours were found to be lower than normal except during $1^{\text {st }}, 2^{\text {nd }}, 7^{\text {th }}, 8^{\text {th }}, 9^{\text {th }}, 11^{\text {th }}$ to $13^{\text {th }}, 15^{\text {th }}$ and $16^{\text {th }}$ standard meteorological week it was higher than normal. The bright sunshine hours was 0.1 to 1.3 hours higher than normal and -8.5 to -0.2 hours lower than normal in different standard meteorological weeks. Evaporation during different weeks in the rabi 2016-17 was observed to be lower than normal except during $1^{\text {st }}, 2^{\text {nd }}, 3^{\text {rd }}, 5^{\text {th }}$ to 9 th and $13^{\text {th }}$ standard meteorological weeks, it was more than normal. During $10^{\text {th }}$ and $12^{\text {th }}$ standard meteorological weeks, it was equal to the normal value. The difference between observed and normal pan evaporation was -2.2 to $1.2 \mathrm{~mm} /$ day during different standard meteorological weeks. The pan evaporation was 0.0 to 1.2 $\mathrm{mm}$ /day higher than normal and -2.2 to $-0.3 \mathrm{~mm}$ /day lower than normal in different standard meteorological weeks. Wind speed was found to be lower than normal except $48^{\text {th }}, 1^{\text {st }}$ to $4^{\text {th }}, 6^{\text {th }}, 8^{\text {th }}$ to $10^{\text {th }}$ and $13^{\text {th }}$ to $16^{\text {th }}$ standard meteorological weeks it was higher than normal value. During $7^{\text {th }}$ standard meteorological weeks, it was equal to the normal value. The difference between observed and normal wind speed was -2.7 to $2.8 \mathrm{~km} /$ hours during different standard meteorological weeks. The wind speed 
was 0.4 to $2.8 \mathrm{~km} /$ hours higher than normal and -2.7 to -0.2 $\mathrm{km} /$ hours lower than normal in different standard meteorological weeks. Relative humidity measured at 7.21 AM was found to be higher than normal, except $48^{\text {th }}$ standard meteorological weeks it was lower than normal value. The difference between observed and normal maximum relative humidity during different standard meteorological weeks was 0.9 to 16.1 . The maximum relative humidity was 0.0 to 16.1 higher than normal and -0.9 lower than normal in different standard meteorological weeks. Relative humidity measured at $2.21 \mathrm{PM}$ was found to be higher than normal, except $47^{\text {th }}, 51^{\text {th }}$, $52^{\text {th }}, 2^{\text {nd }}$ and $8^{\text {th }}$ standard meteorological weeks it was lower than normal value. The Relative humidity measured at 2.21 PM was 0.6 to 25.9 higher than normal and -8.4 to -2.1 lower than normal in different standard meteorological weeks. The difference between observed and normal minimum relative humidity during different standard meteorological weeks was 8.4 to 25.9 .

\begin{tabular}{|l|l|l|l|l|}
\hline $\begin{array}{l}\text { Date of } \\
\text { Sowing }\end{array}$ & $\begin{array}{l}\text { Regression } \\
\text { Equation }\end{array}$ & $\begin{array}{l}\text { Predicted } \\
\text { Yield } \\
\text { kg/ha })\end{array}$ & $\begin{array}{l}\text { Observed } \\
\text { Yield } \\
\text { (kg/ha) }\end{array}$ & $\begin{array}{l}\text { \% } \\
\text { Devia } \\
\text { tion }\end{array}$ \\
\hline \multicolumn{5}{|l|}{ Estimated yield of wheat crop at flowering stage } \\
\hline $\begin{array}{l}\text { Normal } \\
\text { Sowing }\end{array}$ & $\begin{array}{l}2023.8+1.60 * Z 23 \\
1+3.57 * Z 121+48 . \\
04 * \text { Time }\end{array}$ & 5015 & 4916 & 2.0 \\
\hline $\begin{array}{l}\text { Late } \\
\text { Sowing }\end{array}$ & $\begin{array}{l}1520.9+1.66 * Z 23 \\
1+0.49 * Z 141+50 . \\
9 * \text { Time }\end{array}$ & 4907 & 4566 & 7.5 \\
\hline $\begin{array}{l}\text { Very } \\
\text { late } \\
\text { Sowing }\end{array}$ & $\begin{array}{l}2063.11+0.19 * Z 3 \\
51+0.45 * Z 141+4 \\
8.74 * \text { Time }\end{array}$ & 4347 & 4645 & -6.4 \\
\hline Average & & 4756.1 & 4709.0 & 1.01 \\
\hline Estimated yield of wheat crop at grain filling stage & \\
\hline $\begin{array}{l}\text { Normal } \\
\text { Sowing }\end{array}$ & $\begin{array}{l}2684.41+0.09 * Z 3 \\
51+64.9 * Z 21+41 . \\
55 * T i m e\end{array}$ & 4666 & 4916 & -5.1 \\
\hline $\begin{array}{l}\text { Late } \\
\text { Sowing }\end{array}$ & $\begin{array}{l}4150+0.09 * Z 351 \\
+52.13 * Z 11+42.6 \\
7 * \text { Time }\end{array}$ & 4574 & 4566 & 0.2 \\
\hline $\begin{array}{l}\text { Very } \\
\text { late } \\
\text { Sowing }\end{array}$ & $\begin{array}{l}2279.83+0.11 * Z 4 \\
51+0.47 * Z 141+4 \\
9.60 * \text { Time }\end{array}$ & 4425 & 4645 & -4.7 \\
\hline Average & & 4554.7 & 4709.0 & -3.27 \\
\hline
\end{tabular}

Table 1: Percentage deviation of observed yield from estimated yield of wheat crop by weather based model (Rabi 2016-17)

\begin{tabular}{|c|c|c|c|}
\hline Date of sowing & $\begin{array}{l}\text { Predicted } \\
\text { Yield } \\
(\mathrm{kg} / \mathrm{ha}) \\
\end{array}$ & $\begin{array}{l}\text { Observed } \\
\text { Yield } \\
(\mathrm{kg} / \mathrm{ha}) \\
\end{array}$ & $\begin{array}{l}\% \\
\text { Deviation }\end{array}$ \\
\hline \multicolumn{4}{|c|}{ Estimated yield of wheat crop at flowering stage } \\
\hline Normal Sowing & 5126 & 4916 & 4.3 \\
\hline Late Sowing & 4825 & 4566 & 5.7 \\
\hline Very late Sowing & 4785 & 4645 & 3.0 \\
\hline Average & 4912.0 & 4709.0 & 4.31 \\
\hline \multicolumn{4}{|c|}{ Estimated yield of wheat crop at grain filling stage } \\
\hline Normal Sowing & 5017.8 & 4916 & 2.1 \\
\hline Late Sowing & 4818.0 & 4566 & 5.5 \\
\hline Very late Sowing & 4494.0 & 4645 & -3.3 \\
\hline Average & 4776.6 & 4709.0 & 1.44 \\
\hline
\end{tabular}

Table 2: Percentage deviation of observed yield from estimated yield of wheat crop by InfoCrop model (Rabi 2016-17)

\section{Multi Stage Wheat Crop Yield Estimation Using Weather Based Statistical, InfoCrop and DSSAT Model During Rabi 2016-17}

Wheat crop yield estimation done at flowering and grain filling stage by weather based statistical model is given in table 1 . Percentage deviation of estimated yield done at flowering and grain filling stage as compared with the observed yield after harvest was $2.0,7.5,-6.4$ and $-5.1,0.2,-4.7$ respectively for normal, late and very late sown crop. The percentage deviation of average yield estimation done at flowering and grain filling stage was 1.01 and -3.27 as compared to the average observed yield after harvest. Using InfoCrop model, percentage deviation of estimated yield done at flowering and grain filling stage as compared with the observed yield after harvest was 4.3, 5.7, 3.0 and $2.1,5.5,-3.3$ respectively for normal, late and very late sown crop (Table 2). Percentage deviation of average estimated yield from average observed yield done at flowering and grain filling stage by InfoCrop model was 4.31 and 1.44 respectively. Using DSSAT model the percentage deviation of estimated yield done at flowering and grain filling stage as compared with the observed yield after harvest was -10.2, -9.8, -15.7 and -9.0, $8.2,-12.3$ respectively for normal, late and very late sown crop. Percentage deviation of average estimated yield from average observed yield at flowering and grain filling stage was -9.7 and -8.4 respectively (Table 3 )

\begin{tabular}{|l|l|l|l|}
\hline Date of sowing & $\begin{array}{l}\text { Predicted } \\
\text { Yield } \\
(\mathrm{kg} / \mathrm{ha})\end{array}$ & $\begin{array}{l}\text { Observed } \\
\text { Yield } \\
(\mathrm{kg} / \mathrm{ha})\end{array}$ & $\begin{array}{l}\% \\
\text { Deviation }\end{array}$ \\
\hline Estimated yield of wheat crop at flowering stage \\
\hline Normal Sowing & 4415 & 4916 & -10.2 \\
\hline Late Sowing & 4119 & 4566 & -9.8 \\
\hline Very late Sowing & 3918 & 4645 & -15.7 \\
\hline Average & 4250 & 4709 & -9.7 \\
\hline Estimated yield of wheat crop at grain filling stage \\
\hline Normal Sowing & 4472 & 4916 & -9.0 \\
\hline Late Sowing & 4191 & 4566 & -8.2 \\
\hline Very late Sowing & 4073 & 4645 & -12.3 \\
\hline Average & 4312 & 4709 & -8.4 \\
\hline
\end{tabular}

Table 3: Percentage deviation of observed yield from estimated yield of wheat crop by DSSAT model (Rabi 2016-17)

\section{Weather during Rabi 2017-18 at IARI, New Delhi}

The maximum temperature during different standard meteorological weeks in the Rabi 2017-18 was observed to be lower than normal except during $52^{\text {nd }}$ to $3^{\text {rd }}, 5^{\text {th }}$ to $14^{\text {th }}$ and $16^{\text {th }}$ standard meteorological week it was found to be higher than normal. The difference between normal and observed maximum temperature was -3.3 to 5.0 in different standard meteorological weeks. The minimum temperature remain lower than normal except during $8^{\text {th }}, 9^{\text {th }}, 12^{\text {th }}$ to $14^{\text {th }}$ and $16^{\text {th }}$ standard meteorological weeks it was higher than normal. The minimum temperature was 0.2 to $2.3^{\circ} \mathrm{C}$ higher than normal and -4.9 to $0.1^{\circ} \mathrm{C}$ lower than normal in different standard meteorological weeks. Total rainfall of $32.4 \mathrm{~mm}$ (normal value $95.4 \mathrm{~mm}$ ) was received during Rabi $2017-18$ on $50^{\text {th }}, 4^{\text {th }}, 14^{\text {th }}$, and $15^{\text {th }}$ standard meteorological weeks. The rainfall during the Rabi season was less than the normal. However, the rainfall was received in 4 out of 24 weeks of this season. Bright sunshine hours were found to be lower than normal except during $2^{\text {nd }}, 3^{\text {rd }}$, $5^{\text {th }}, 12^{\text {th }}$, and $13^{\text {th }}$ standard meteorological week it was higher than normal. The bright sunshine hours was 0.1 to 1.8 hours higher than normal and -9.0 to -0.1 hours lower than normal in 
different standard meteorological weeks. Evaporation during different weeks in the Rabi 2017-18 was observed to be lower than normal except during $2^{\text {nd }}$ to $9^{\text {th }}$ and $12^{\text {th }}$ standard meteorological weeks it was higher than normal. The difference between observed and normal pan evaporation was -3.7 to 0.9 $\mathrm{mm} /$ day during different standard meteorological weeks. The pan evaporation was 0.1 to $0.9 \mathrm{~mm} /$ day higher than normal and -3.7 to $-0.1 \mathrm{~mm} /$ day lower than normal in different standard meteorological weeks. Wind speed was found to be lower than normal except $2^{\text {nd }}, 4^{\text {th }}, 5^{\text {th }}, 7^{\text {th }}, 9^{\text {th }}, 10^{\text {th }}, 13^{\text {th }}$ and $16^{\text {th }}$ standard meteorological weeks it was higher than normal value. During $51^{\text {st }}$ and $12^{\text {th }}$ standard meteorological weeks it was equal to the normal value. The difference between observed and normal wind speed was -3.2 to $1.8 \mathrm{~km} /$ hours during different standard meteorological weeks. The wind speed was 0.1 to $1.8 \mathrm{~km} /$ hours higher than normal and -3.2 to $-0.1 \mathrm{~km} /$ hours lower than normal in different standard meteorological weeks. Relative humidity measured at 7.21 AM was found to be higher than normal, except $49^{\text {th }}, 51^{\text {st }}, 13^{\text {th }}, 14^{\text {th }}$ and $16^{\text {th }}$ standard meteorological weeks it was lower than normal value. The difference between observed and normal maximum relative humidity during different standard meteorological weeks was -3.7 to 12.1 . The maximum relative humidity was 0.0 to 12.1 higher than normal and -3.7 lower than normal in different standard meteorological weeks. Relative humidity measured at $2.21 \mathrm{PM}$ was found to be higher than normal, except $51^{\text {st }}, 2^{\text {nd }}, 3^{\text {rd }}, 5^{\text {th }}, 6^{\text {th }}, 8^{\text {th }}, 10^{\text {th }}$ to $14^{\text {th }}$ and $16^{\text {th }}$ standard meteorological weeks it was lower than normal value. The Relative humidity measured at $2.21 \mathrm{PM}$ was 2.0 to 19.0 higher than normal and -11.4 to -0.1 lower than normal in different standard meteorological weeks. The difference between observed and normal minimum relative humidity during different standard meteorological weeks was 11.4 to 19.0 .

\begin{tabular}{|c|c|c|c|c|}
\hline $\begin{array}{l}\text { Date of } \\
\text { Sowing }\end{array}$ & $\begin{array}{l}\text { Regression } \\
\text { Equation }\end{array}$ & $\begin{array}{l}\text { Predicted } \\
\text { Yield } \\
(\mathrm{kg} / \mathrm{ha})\end{array}$ & $\begin{array}{l}\text { Observ } \\
\text { ed } \\
\text { Yield } \\
(\mathrm{kg} / \mathrm{ha}) \\
\end{array}$ & $\begin{array}{l}\% \\
\text { Devia } \\
\text { tion } \\
\end{array}$ \\
\hline \multicolumn{5}{|c|}{ Estimated yield of wheat crop at flowering stage } \\
\hline $\begin{array}{l}\text { Normal } \\
\text { Sowing }\end{array}$ & $\begin{array}{l}\text { Yield }=2692+47.9 * \mathrm{Ti} \\
\text { me+1.39*Z231+0.48 } \\
* \mathrm{Z} 251\end{array}$ & 4380 & 4623 & 5.3 \\
\hline $\begin{array}{l}\text { Late } \\
\text { Sowing }\end{array}$ & $\begin{array}{l}\text { Yield }=2270.2+43.9 \\
* \text { Time }+0.22 * \text { Z351 } \\
+0.28 * \mathrm{Z} 151\end{array}$ & 4438 & 4474 & 0.8 \\
\hline $\begin{array}{l}\text { Very late } \\
\text { Sowing }\end{array}$ & $\begin{array}{l}\text { Yield }=2781.1+47.5^{*} \\
\text { Time }+0.28 * \mathrm{Z} 351\end{array}$ & 4452 & 4198 & -6.1 \\
\hline \multicolumn{2}{|c|}{ Average } & 4423.2 & 4431.3 & 0.18 \\
\hline \multicolumn{5}{|c|}{ Estimated yield of wheat crop at grain filling stage } \\
\hline $\begin{array}{l}\text { Normal } \\
\text { Sowing }\end{array}$ & $\begin{array}{l}\text { Yield }=2056.8 \\
+46.3 * \text { Time }+ \\
0.16 * \text { Z351 }+0.21 * \\
\text { Z141 }\end{array}$ & 4351 & 4623 & 5.9 \\
\hline $\begin{array}{l}\text { Late } \\
\text { Sowing }\end{array}$ & $\begin{array}{l}\text { Yield }=2162.9 \\
+46.1 * \text { Time }+ \\
0.16 * \text { Z351 +0.25 } \\
* \text { Z141 }\end{array}$ & 4354 & 4474 & 2.7 \\
\hline $\begin{array}{l}\text { Very late } \\
\text { Sowing }\end{array}$ & $\begin{array}{l}\text { Yield }=2427+42.7 \\
* \text { Time }+0.12 * \\
\mathrm{Z} 351+0.84 * \mathrm{Z} 151 \\
-0.10 * \mathrm{Z} 150\end{array}$ & 4427 & 4198 & -5.5 \\
\hline Average & & 4377.5 & 4431.3 & 1.21 \\
\hline
\end{tabular}

Table 4: Percentage deviation of observed yield from estimated yield of wheat crop by weather based model (Rabi 2017-18)

\section{Multi Stage Wheat Crop Yield Estimation Using Weather Based Statistical, InfoCrop and DSSAT Model During Rabi 2017-18}

Wheat crop yield estimation done at flowering and grain filling stage by weather based statistical model is given in table 4 . Percentage deviation of estimated yield done at flowering and grain filling stage as compared with the observed yield after harvest was 5.3, 0.8, -6.1 and 5.9, 2.7, -5.5 respectively for normal, late and very late sown crop. The percentage deviation of average yield estimation done at flowering and at grain filling stage was 0.18 and 1.21 as compared to the average observed yield after harvest.

\begin{tabular}{|c|c|c|c|}
\hline Date of sowing & \begin{tabular}{|l} 
Predicted \\
Yield \\
$(\mathrm{kg} / \mathrm{ha})$
\end{tabular} & $\begin{array}{l}\text { Observed } \\
\text { Yield } \\
(\mathrm{kg} / \mathrm{ha})\end{array}$ & $\begin{array}{l}\% \\
\text { Deviation }\end{array}$ \\
\hline \multicolumn{4}{|c|}{ Estimated yield of wheat crop at flowering stage } \\
\hline Normal Sowing & 4725 & 4623 & 2.2 \\
\hline Late Sowing & 4726 & 4474 & 5.6 \\
\hline Very late Sowing & 4338 & 4198 & 3.3 \\
\hline Average & 4634.3 & 4431.3 & 4.58 \\
\hline \multicolumn{4}{|c|}{ Estimated yield of wheat crop at grain filling stage } \\
\hline Normal Sowing & 4725.0 & 4623.0 & 2.2 \\
\hline Late Sowing & 4725.5 & 4473.5 & 5.6 \\
\hline Very late Sowing & 4046.5 & 4197.5 & -3.6 \\
\hline Average & 4499.0 & 4431.3 & 1.53 \\
\hline
\end{tabular}

Table 5: Percentage deviation of observed yield from estimated yield of wheat crop by InfoCrop model (Rabi 2017-18

\begin{tabular}{|l|l|l|l|}
\hline Date of sowing & $\begin{array}{l}\text { Predicted } \\
\text { Yield } \\
(\mathrm{kg} / \mathrm{ha})\end{array}$ & $\begin{array}{l}\text { Observed } \\
\text { Yield } \\
(\mathrm{kg} / \mathrm{ha})\end{array}$ & $\begin{array}{l}\% \\
\text { Deviation }\end{array}$ \\
\hline Estimated yield of wheat crop at flowering stage \\
\hline Normal Sowing & 4122 & 4623 & -10.8 \\
\hline Late Sowing & 4027 & 4474 & -10.0 \\
\hline Very late Sowing & 3471 & 4198 & -17.3 \\
\hline Average & 3873.3 & 4431.7 & -12.59 \\
\hline Estimated yield of wheat crop at grain filling stage \\
\hline Normal Sowing & 4179 & 4623 & -9.6 \\
\hline Late Sowing & 4099 & 4474 & -8.4 \\
\hline Very late Sowing & 3626 & 4198 & -13.6 \\
\hline Average & 3967.7 & 4431.7 & -10.46 \\
\hline
\end{tabular}

Table 6: Percentage deviation of observed yield from estimated yield of wheat crop by DSSAT model (Rabi 2017-18)

Using InfoCrop model, percentage deviation of estimated yield done at flowering and grain filling stage as compared with the observed yield after harvest was 2.2, 5.6, 3.3 and 2.2, 5.6, -3.6 respectively for normal, late and very late sown crop (Table 5). Percentage deviation of average estimated yield from average observed yield done at flowering and grain filling stage by InfoCrop model was 4.58 and 1.53 respectively. Using DSSAT model the percentage deviation of estimated yield done at flowering and grain filling stage as compared with the observed yield after harvest was $-10.8,-10,-17.3$ and $-9.6,-8.4,-13.6$ respectively for normal, late and very late sown crop. Percentage deviation of average estimated yield from average observed yield at flowering and grain filling stage was -12.59 and -10.46 respectively (Table 6). 


\section{CONCLUSION}

Results from the simulated studies showed that the statistical models based upon the weather indices could successfully estimate multistage yield of wheat under semi-arid region. This model is simple, does not required any sophisticated statistical tools, required only weather data for crop growing periods, yield data for past thirty year and provides good multi stage crop yield estimation. This model is most consistent. Therefore, it can be used for district, agro climatic zone and state level crop yield estimation. From the studies, it was concluded that among the three models opted for estimating the yield at flowering and grain filling stage, InfoCrop model gave better results followed by weather based model and DSSAT model. Hence, InfoCrop model can be used for multistage crop yield estimation.

\section{ACKNOWLEDGEMENT}

Authors are thankful to Director IARI, New Delhi for providing the facilities and also India Meteorological Department, New Delhi for funding the research project.

\section{REFERENCES}

Aggarwal, P.K., Kalra, N., Chader, S. and Pathak, H., 2006. Infocrop: a dynamic simulative model for the assessment of crop yields losses due to pests, and environmental impact of agro-ecosystems in tropical environments. I. Performance of the model. Agricultural Systems, 89, pp. 47-67.
Agrawal, R., Chandrahas and Kaustav A., 2012. Use of discriminant function analysis for forecasting crop yield. Mausam, 63 (3), pp. 455-458

Ghosh, K., Balasubramanian, R., Bandopadhyay, S., Chattopadhyay, N., Singh K. K. and Rathore, L., 2014. Development of crop yield forecast models under FASAL -a case study of kharif rice in West Bengal. Journal of Agrometeorology, 16(1), pp. 1-8.

Hebbar, K.B.,Venugopalan, M.V., Seshasai, M.V.R, Rao, K.V., Patil, B.C., Prakash, A.H., Kumar,V., Hebbar, K.R., Jeyakumar, P., Badopadhyay, K.K., Rao, M.R.K., Khadi, B.M., Aggarwal, P.K., 2008. Predicting cotton production using Infocrop-cotton simulation model, remote sensing and spatial agro-climatic data. Current Science, 95, pp. 570-579.

Singh, J.P., Govindakrishnan, P.M., Lal, S.S. and Aggarwal, P.K., 2005. Increasing the efficiency of agronomic experiments in potato using Infocrop-potato model. Potato Research. 48, pp.131-152.

Vashisth, Ananta, Singh, R. and Choudary, Manu. 2014. Crop yield forecast at different growth stage of wheat crop using statistical model under semi-arid region. Journal of Agroecoogy and Natural Resource Management, pp. 1-3.

Vashisth, Ananta, Choudary, M., Joshi, D. K. and Baloda, R. (2015). Pre harvest yield forecast in maize-mustard cropping system under semi-arid region using crop simulation model. International Journal of Tropical Research. 33 (2), pp.10591067. 